\title{
DEVELOPMENT OF U-CHANNEL SCREW JACK FOR VEGETABLE OIL EXTRACTION
}

\author{
M. M. Odewole ${ }^{1}$, M. O. Sunmonu ${ }^{2}$, S. K.Oyeniyi ${ }^{3,{ }^{*},}$, O. A. Adesoye ${ }^{4}$ and P. P. Ikubanni ${ }^{5}$ \\ 1, 2 DEPARTMENT OF FoOd ENGINEERING, UNIVERSITY OF ILORIN, ILORIN, KWARA STATE, NIGERIA. \\ 3 DEPT. OF AGRICULTURAL AND ENVIRONMENTAL ENGR., UNIVERSITY OF IBADAN, IBADAN, OYO STATE, NIGERIA. \\ 4 DEPARTMENT OF MECHANICAL ENGINEERING, UNIVERSITY OF ILORIN, ILORIN, KWARA STATE, NIGERIA. \\ 5 DEPARTMENT OF MECHANICAL ENGINEERING, LANDMARK UNIVERSITY, OMU-ARAN, KWARA STATE, NIGERIA \\ Email addresses:1 odewole2005@yahoo.com, ${ }^{2}$ sholams2000@yahoo.co.uk, ${ }^{3}$ oyeniyisk@gmail.com, \\ ${ }^{4}$ oluwatosinadesoye@yahoo.com, ${ }^{5}$ ikubanni.peter@Imu.edu.ng
}

\begin{abstract}
A U-channel screw jack for extracting vegetable oil was developed through design (with Solid works-Computer Aided Design (CAD)) and fabrication processes. A $3 \times 2$ factorial experiment in a Randomized Complete Block Design (RCBD) was used to investigate the effect of heating temperature $\left(50,60\right.$ and $70^{\circ} \mathrm{C}$ ) and heating time (5 and $\left.10 \mathrm{~min}\right)$ on the performance of the machine in terms of oil yield, extraction efficiency and extraction loss with groundnut as the feedstock. Results of the machine design for some of the machine components gave the following values: U-channel structural frame made of mild steel $(80 \times 160 \times 650 \mathrm{~mm})$, compression cap $(\varnothing 70 \mathrm{~mm})$ and heater band(3.5kW). Also, the performance evaluation of the machine showed that increase in heating temperature $\left(50\right.$ to $\left.70^{\circ} \mathrm{C}\right)$ and heating time ( 5 to $10 \mathrm{~min}$ ) did not cause the oil yield, extraction efficiency and extraction loss to increase beyond $30 \%$, 48\% and 15\% respectively. Generally, decrease in oil yield, extraction efficiency and extraction loss occurred at the heating temperature of $70^{\circ} \mathrm{C}$ irrespective of the heating time. For future works, other machine and feedstock factors should be incorporated into the performance evaluation process. Also, automation of the machine is recommended.
\end{abstract}

Keywords: Design, U-channel screw jack, vegetable oil extraction, test analysis

\section{INTRODUCTION}

Vegetable oils are oils of plants origin [1] and can be generally classified as edible or non-edible; this classification depends on whether the parent parts of plants that contain the oil are edible or not. Some of the edible vegetable oils are groundnut oil, soybean oil, melon oil and sesame oil; examples of typical non-edible vegetable oils are the vetia oil, castor oil and jatropha oil [2]. The world production of oil seed stocks was estimated to be about 40 million tons between 2003 and 2004 [3]. Vegetable oils contain some essential nutrients like fat, minerals, protein and vitamins [4] and they are used as cooking oil and as part of raw materials for making paints, detergent, soap and cosmetics $[5,6]$.

Vegetable oil extraction is the process of liberating oil from oil cells that are naturally embedded in plant materials. It is one of the important unit operations in vegetable oil processing, and the process is achieved through the application of pressure, temperature, chemical concentration gradient and any other external influence or their combinations than what the oil cells can withstand. Odewole, et al., [7] reported mechanical extraction (hydraulic press and screw press), traditional extraction, super critical fluid extraction and solvent extraction as methods of oil extraction from oil seeds. Nwabanne [8] stated that solvent extraction method bridged the gap between mechanical extraction (which usually produces oil with high turbidity and water content) and supercritical fluid extraction which is very expensive to build and maintain; thus, the method (solvent extraction) was considered as the most common method of extraction of oil because it has the tendency to recover high percentage of oil from oilseeds. Isobe et al., [9] developed a screw press based on twin screw and reported oil recovery of over $93 \%$ from untreated dehulled sunflower seed. Akerele and Ejiko [10] used horizontal expeller for oil extraction from groundnut and got average extraction efficiency of $72.94 \%$. Adetola et al., [11] developed a horizontal screw press for palm oil extraction and got oil extraction efficiency and oil extraction ratio of $79.56 \%$ and $17.90 \%$ respectively. Also, [12] reported that prolonged heating time of groundnut above $25 \mathrm{~min}$ at greater than $90^{\circ} \mathrm{C}$ will not lead to the improvement of oil yield; although, Tunde-Akintunde et 
al. [13] reported increase in oil yield for mechanically expressed soybeans oil at temperature in the range of 70 to $80^{\circ} \mathrm{C}$ and heating time of 15 to $30 \mathrm{~min}$. Furthermore, Akinoso et al., reported optimum oil yield equivalent extraction efficiency of $50.4 \%, 90.1 \%$ respectively at roasting temperature of $124.2^{\circ} \mathrm{C}$ and roasting time of 13 min from mechanically expressed oil from sesame seed. For Akinoso [1], 47.0\% oil yield was obtained from palm kernel using mechanical extraction process. Olaniyan [14] wrote that maximum oil yield of $39.6 \%$ which is equivalent to extraction efficiency of $66 \%$ was obtained at $65^{\circ} \mathrm{C}$ for $28 \mathrm{~min}$ from milled conophor nut. Ajibola [23] reported $64 \%$ extraction efficiency from palm kernel, and Odewole et al., [7] reported extraction loss of between 2.495 - 16.122\% when solvent extraction method was used to extract oil from fluted pumpkin seed.

Vegetable oils have been a universal demand due to their high rate of uses both domestically and industrially. There are several methods of extracting vegetable oils as earlier mentioned. The mechanical oil extraction have some disadvantages that can reduce the quality and yield of oil extracted. The power requirement for motorized screw press is high and its operation is very tedious and its components are bulky; also, the hydraulic oil from hydraulic press can spill into the extraction medium, which will contaminate the needed oil and could change its chemical composition. Likewise, some of the chemicals (solvents) for extracting oils during solvent extraction can mix with the needed oil; this may be very difficult and expensive to separate, and the presence of such chemicals in the extracted oils could lead to some adverse effects in the body when consumed or formation of unpleasant compounds when used to make other products. Furthermore, the traditional method of oil extraction is full of drudgery and the output is very low. In order to reduce some of the aforementioned problems, the use of a U-channel screw jack to extract vegetable oil was considered. Therefore, the main objective of this research was to develop a U-channel screw jack for vegetable oil extraction. The specific objective was to investigate the effect of two process conditions (heating temperature and heating time) on the performance indices (oil yield, extraction loss and extraction efficiency) of the machine.

\section{MATERIALS AND METHODS}

This study was dealt with in five parts. First part of this study involved detailed design calculations of the machine element; the second part was the modeling of the Uchannel section(made of mild steel) and analysis of stresses and displacement under actual load conditions. In this part, the CAD model of the U-channel section was developed in 3D modeling software, Solid works 2014. The stress analysis and stiffness of the models were then obtained in Solid works Simulation (Static Structural).The third part was the thermal analysis; the fourth was the fabrication of the machine and the fifth was the performance evaluation. The static structural analysis of the frame was done in Solid works 2014 in order to predict how the U-Channel will perform under load and to detect potential problems early in the design cycle. The numerical simulation was executed on a 64-bit PC, Intel Core $^{\mathrm{TM}}$ p-8600 processor at $2.4 \mathrm{GHz}, 4 \mathrm{~GB}$ RAM and was conducted under the Windows 7 operating system Professional, whereby Von Mises stress, strain and deformation analyses were carried out. The performance evaluation of the U-channel screw jack (in terms of oil yield, extraction efficiency and extraction loss) was done with groundnut as feed stock.

\subsection{Machine Elements Design}

\subsubsection{Design Considerations}

The design of the machine elements was based on the shape and material of construction. These two factors were put into consideration in the design and for the structural analysis of the machine since they are the determining factors that stiffness depends on. Stiffness is one of the major properties of a part or assembly that characterizes its response to the applied load[15].

\subsubsection{Design of the Compression Piston}

The relationship between the piston diameter and the cylinder diameter is given by the following expression [16]

$$
D_{p}=\frac{D_{i}}{1.0004}=0.0749 \mathrm{~m}
$$

Where $D_{p}$ is the piston diameter, $m$ and $D_{i}$ is the Internal diameter, $(0.075 m)$

\subsubsection{Design of Press Cage Cylinder}

The maximum pressure that can be exerted on the crushed seed in the press cage cylinder during the process was calculated by equation 2 , where

$$
P=\frac{F}{A}=47511.312 \mathrm{~N} / \mathrm{m}^{2}
$$

Where $P$ is the Maximum pressure exerted, $N / m^{2}, F$ is the Maximum load applied, $(210 N), D_{i}$ is the Internal diameter, $(0.075 \mathrm{~m})$, and $A$ is the Base area of the cage cylinder $\left(0.00442 \mathrm{~m}^{2}\right)$.

\subsubsection{Design of Press Cage Perforator}

For the perforation of the press cage base, holes of ( $3 \mathrm{~mm}$ diameter) were to be drilled in the section of the supporting platform within the press cage cylinder's circumference. Hence, the total number of the holes forms about $12.5 \%$ of the area of this serves as the drainage area of the extracted oil was calculated according to (3) 


$$
N=0.125\left(\frac{D_{i}}{D_{h}}\right)^{2}=10.98
$$

In (3), $N$ is the Numbers of holes to be drilled, $D_{i}$ is the Internal diameter, $(0.075 \mathrm{~m})$, and $D_{h}$ is the Diameter of each hole of the base perforation, $(0.008 \mathrm{~m})$

Therefore, for this design, not less than 15 holes were drilled on the plate for easy discharge of the extracted oil.

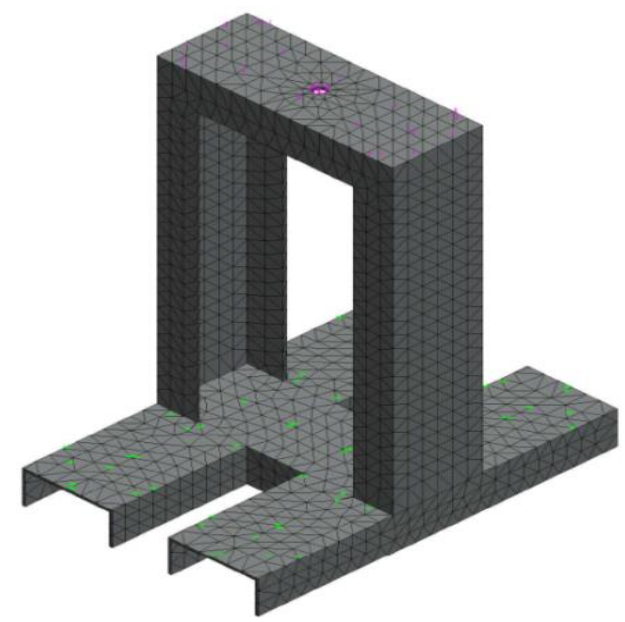

Fig. 1: Discretization of the U-Channel

\subsubsection{Design of the U-Channel or Column:}

The supporting base is a built-upon channel of a $\mathrm{U}$ channel section. The Maximum stress that can be experienced by member of the supporting platform is given as:

$$
\delta_{\mathrm{ab}}=\frac{12 \mathrm{P}_{\mathrm{a}} \mathrm{Ly}}{\mathrm{bh}^{3}}
$$

Here, $\delta_{\mathrm{ab}}$ is the stress experienced by member of the supporting platform, $N / m^{2}, \mathrm{P}_{\mathrm{a}}$ is the Maximum applied load for oil extraction, $(210 \mathrm{~N})$, $\mathrm{L}$ is the Effective length of member of supporting platform, $(0.95 \mathrm{~m})$, $\mathrm{y}$ is A function of thickness of the supporting platform, $(0.65 \mathrm{~m}), \mathrm{b}$ is the Length of the supporting platform, $(0.165 \mathrm{~m})$ and $\mathrm{h}$ is the Thickness of the supporting platform, $(0.08 \mathrm{~m})$.

Therefore, the calculated stress by member of the supporting platform was $\delta_{\mathrm{ab}}=21,500 \mathrm{~N} / \mathrm{m}^{2}$

\subsubsection{Power Requirement}

A force $(F)$ is applied at distance $(x)$ from the axis of the cylinder attached to the piston to the bottom of the chamber where the groundnut seeds are being compressed. The turning moment transmitted by the shaft is,

$$
T=F x
$$

Assuming a force of $210 \mathrm{~N}$ can be applied by a man[17] at a speed of $60 \mathrm{rpm}$ and at a distance $0.2 \mathrm{~m}$ from the axis and tangential to the shaft.

The pressure $P$, required from the piston to express the groundnut oil from the seed base on the maximum applicable load is given as:

$$
P=\frac{F}{A}=47.5 \mathrm{kN} / \mathrm{m}^{2}
$$

$P$ is the Pressure required from the piston and $F$ is the Applied force, $(210 \mathrm{~N})$

Therefore, the pressure required from the piston to extract oil from the seed is $47.6 \mathrm{kN} / \mathrm{m}^{2}$.

The power requirement to press the cylinder through the screw jack will express the oil from the groundnut seed based on the maximum applicable load is given as:

$$
P_{x}=\frac{2 \pi N T}{60}=0.263 \mathrm{~kW}
$$

Here, $N$ is the Speed of rotation of the turning screw (60 rpm), and $T$ is and Torque on the shaft, $(105 \mathrm{Nm})$

\subsection{Finite Element Analysis of the U-Channel Frame}

The U-channel section of the machine bears the stress and bending moment brought by the applied force needed to extract oil from the oil bearing seeds. Simulation plug-in in Solid works analyses stresses, strain and factor of safety by static structural analysis. For achieving convenient finite element analysis, the model was simplified by considering the U-Channel frame only, by generally observing the steps as stated by [18] viz; model creation, material definition, meshing, adding constraints and load, operation and results analysis.

\subsubsection{Meshing}

The meshing of the geometry was carried out after creating a new static analysis study in Solid works simulation and defining the material properties, the $3 \mathrm{D}$ model of U-channel was checked to achieve the success of meshing. The method of Aspect ratio and Jacobian was adopted to check the quality of the meshing. Aspect ratio check is defined as the concept that length-width ratio of regular tetrahedron is usually used to calculate the length-width ratio of other units, including the aspect ratio of a very small regular tetrahedron element which can be approximately regarded as 1.0. Jacobian checks the value to judge the bending degree of the unit and ensures all nodes are precisely located in central point of straight edge for regular tetrahedron. In order to ensure the conformity and reliability of U-channel section in finite element analysis (FEA), higher grid density was applied. The formed meshing model of finite element is shown in Figure 1. The size of grid density unit is $2.5211585 \mathrm{~mm}$, tolerance is $0.09408226 \mathrm{~mm}$, and the number of nodes and units are respectively 543320 and 823559.

\subsection{Design of Heat Transfer Element}

In a solid body, the energy is transferred from a high temperature region to a low temperature region. The rate of heat transfer per unit area is proportional to the material thermal conductivity, cross-sectional area and temperature gradient in the normal direction and 
inversely proportional to the distance[19].The heat transfer rate was calculated by using the formula of heat flux through cylindrical pipes given by [20]

$$
Q_{k}=\frac{2 \pi k L\left(T_{i}-T_{o}\right)}{\ln \left(\frac{r_{o}}{r_{i}}\right)}
$$

In (8), $Q_{k}$ is the heat transfer rate, $W, k$ is the thermal conductivity of mild steel, $43 \mathrm{~W} /{ }^{\circ} \mathrm{K} . \mathrm{m}, \mathrm{L}$ is the length of cylinder, $0.165 \mathrm{~m}, \mathrm{~T}_{o}$ is the outside wall temperature, $333^{\circ} \mathrm{K}, T_{i}$ is the inside wall temperature, $343^{\circ} \mathrm{K}, r_{o}$ is the radius of outside wall surfaces, $0.04 \mathrm{~m}$, and $r_{i}$ is the radius of inside wall surfaces, $0.035 \mathrm{~m}$.

The calculated heat transfer rate,3.338 $\mathrm{kW}$, but $3.5 \mathrm{~kW}$ was selected.

\subsection{Thermal Analysis of the Extraction Chamber}

Thermal effects such as temperatures are easy to simulate, but may be quite difficult to measure, especially inside parts or assemblies [19]. This implies that software-based design validation may indeed be the only method available to describe the detailed thermal conditions of the extraction chamber. In lieu of this, the thermal analysis of the extraction chamber was carried out by following the stated steps in Solid works thermal analysis advisor.

Fig. 2 shows the CAD model of the sub-assembly (oil extraction chamber) used for the thermal analysis which was modeled in Solid works 2014, the components part of the sub-assembly were meshed as shown in Fig. 3 and thermal loads were applied to the heater band and the press cage. The calculated heat transfer rate $Q_{k}$ $(3.338 \mathrm{~kW})$, extraction temperature $\left(70^{\circ} \mathrm{C}\right)$ and the thermal properties of the materials used for the components were used as thermal loads in the simulation. The formed mesh model which is shown in Fig. 3 has 23259 nodes and 12231 elements with zero percent distorted Jacobian elements which show that it was properly meshed.

\subsection{Machine Fabrication}

The fabrication of the machine was systematically done according to all the design specifications. Figures 4-6 show the engineering drawings of the machine.

\subsection{Machine Description and Working Principle}

The machine consists of the rigid frame of U-channel section $(80 \times 160 \times 650 \mathrm{~mm})$ made of mild steel, the turning screw (950 $\mathrm{mm}$ long), the compression cap, the perforated cage, cylinder, heater band $(3.5 \mathrm{~kW})$ and the oil collector as shown in Figures 4-6. The turning rod was used to drive the screw into the piston via the column opening which transmits pressure to the cylinder cage.

The machine has two basic working principles which are application of compressive force and heat transfer. The compressive force is exerted and transmitted via the turning of the screw rod caused rupturing of oil cells, thereby leading to liberation of oil into the oil collector via the holes of the oil collector support. Heat was transferred by conduction from the electric heater band to the cylinder, and then to the oil seeds inside the cylinder at regulated temperature and time of heating of not greater than $70^{\circ} \mathrm{C}$ and 10 min respectively.

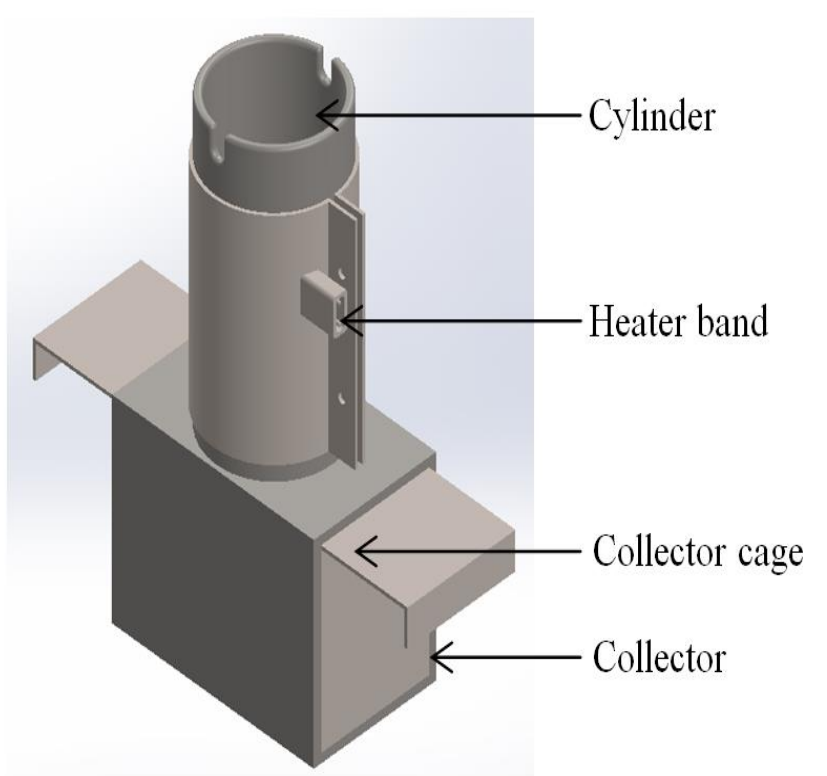

Fig. 2:CAD Model of the sub-assembly

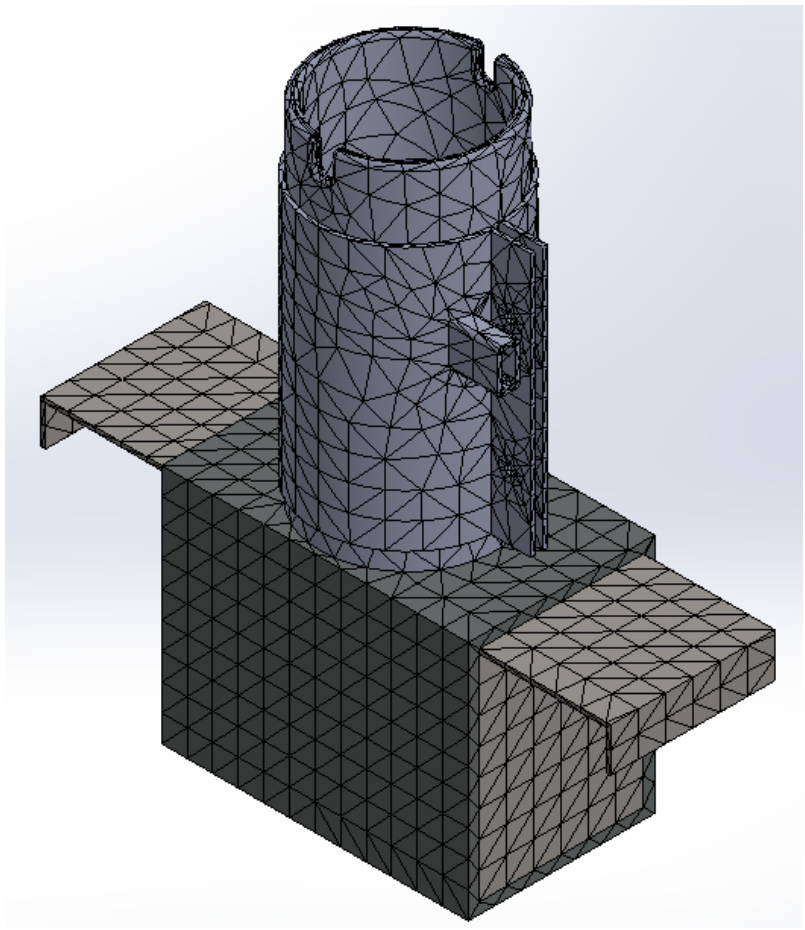

Fig. 3: Discretization of the sub-assembly 


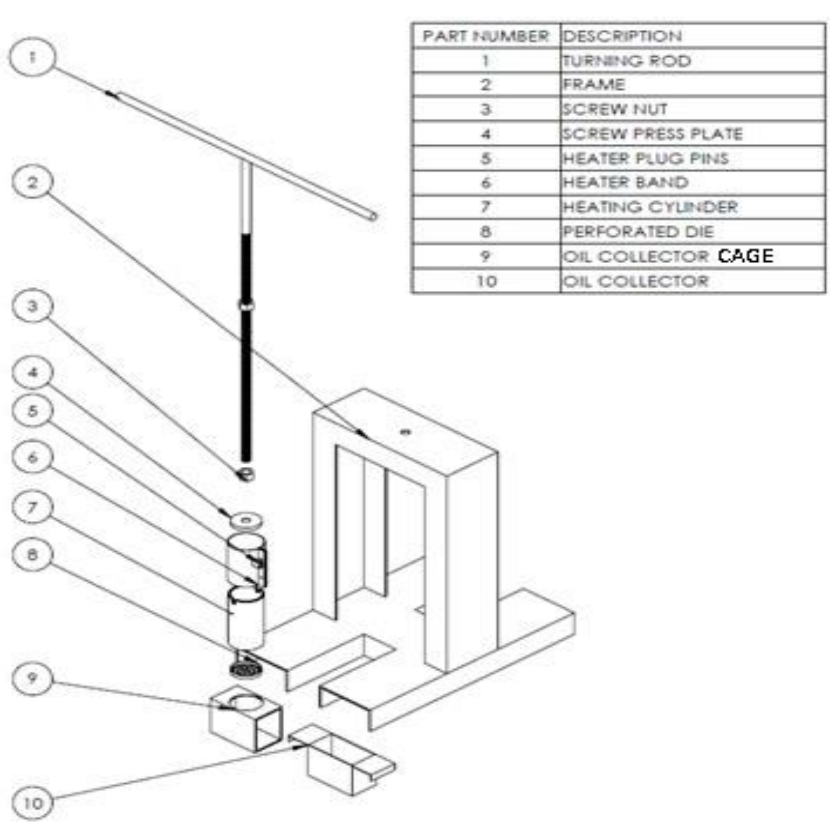

Fig. 4: Exploded View of the Screw Jack (All dimensions are in $\mathrm{mm}$ )

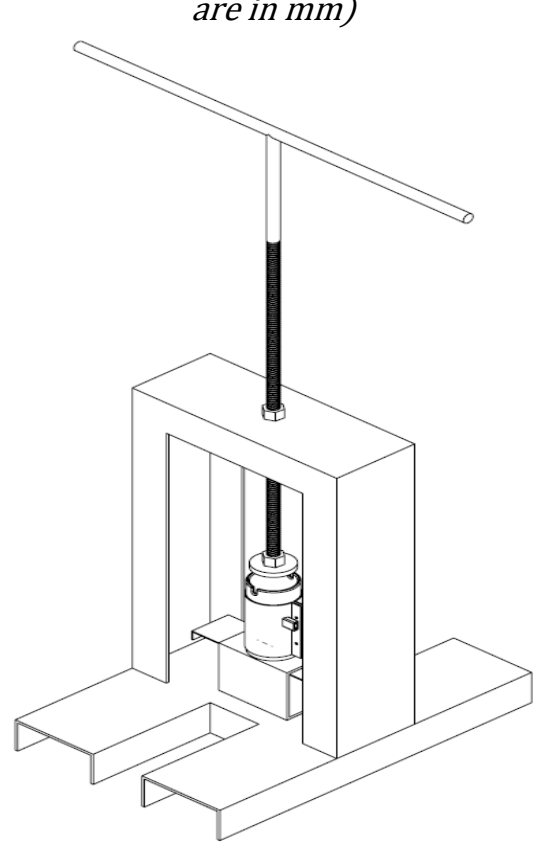

Fig. 5: Isometric View of the Screw Jack

\subsection{Solution and the Analysis of Result}

Finite element model of U-channel was solved using Solid works structural Simulation, and the analysis result that were obtained are the stress distribution as shown in Fig.7the strain distribution (Fig. 6)and the displacement distribution(Fig. 7).The finite element analysis results show that maximum stress is 10.27 $M P a$, and is located in the region where the screw passed. Minimum stress which is $0.152 \mathrm{MPa}$ is located at the base of the section this is as a result that the effect of the turning is not felt at the base and more so it has a good stability since the resultant force is acting at the centre of gravity. Fig. 5 presented that the maximum stress (10.27 $\mathrm{MPa}$ ) of $\mathrm{U}$-channel section is far less than the yield strength (220 MPa); which is in good agreement with the works done by [21]. This invariably is of high advantage since the U-channel section will not fail even at the simulated maximum stress (10.27MPa). Fig. 8 and 9 show that the strain and displacement proportional to the stress distribution. Also, the maximum displacement $(0.002213 \mathrm{~mm})$ occurs in the same region where maximum stress was observed which is in good agreement with Hooke's law that stress is proportional to strain.
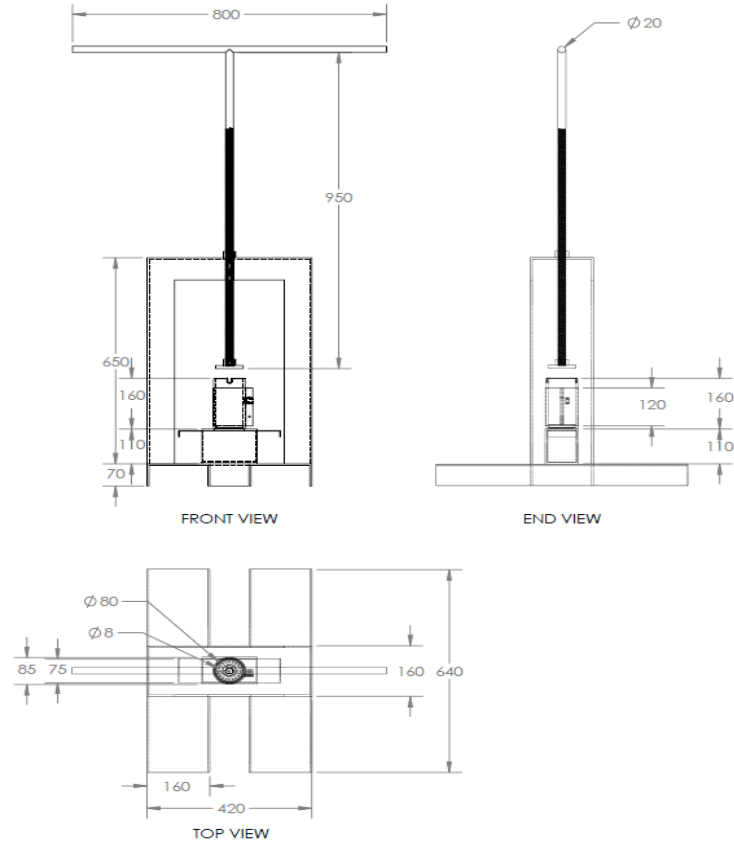

Fig. 6: Orthographic Projections of the Screw Jack

The maximum displacement as shown in Fig. 9 which is very small is an indication of little deformation which is of high advantage in the extraction process. Similar result was reported by [21] in the Finite Element Analysis for Planetary Carrier of Mine Gearbox.

\subsection{Result of Thermal Analysis}

The temperature distribution and resultant heat flux of the extraction chamber are shown in Fig 10 and 11 below. It can be seen from Fig 10 that the required heat is being transferred to the heating cylinder where the oil bearing material will be loaded. Also, the oil collector will be safe to handle since the simulated temperature which is being depicted by the colour blue is in the range of $308-315^{\circ} \mathrm{K}$. From fig 11 the heat flux i.e. heat transferred per unit area is very high around the heating cylinder and this is a good representation of what supposed to happen during the extraction experiment. It was observed that the maximum and minimum heat fluxes are $7 \mathrm{~kW} / \mathrm{m}^{2}$ and $5 \mathrm{~kW} / \mathrm{m}^{2}$. 


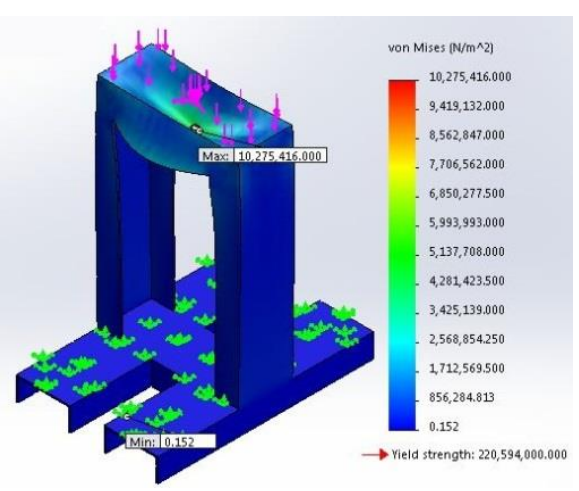

Fig. 7: Von Mises Stress analysis

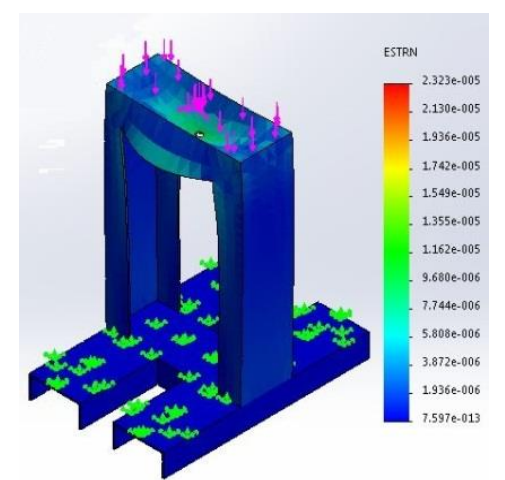

Fig. 8:Maximum Static Strain

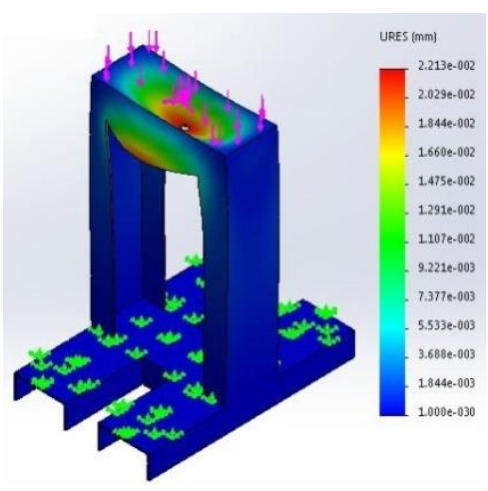

Fig. 9Static Displacement

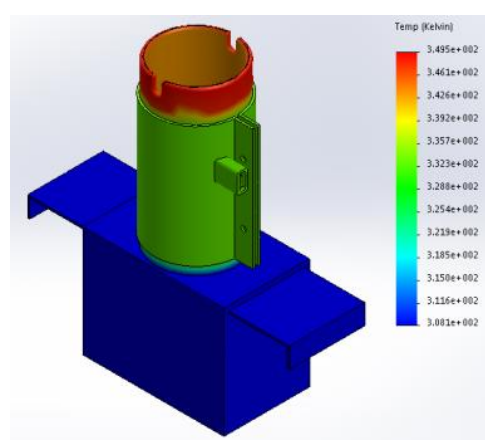

Fig. 10: Temperature Distribution

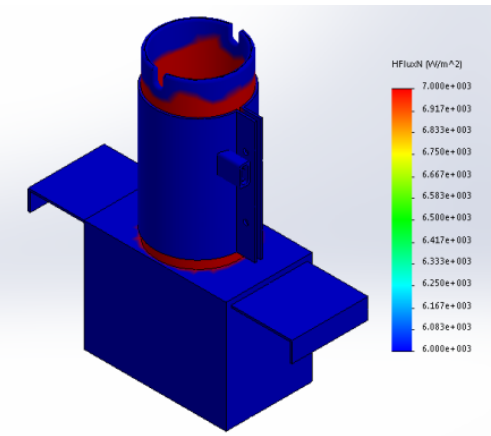

Fig. 11: Resultant Heat Flux

\subsection{Performance Evaluation of the Machine}

The performance evaluation of the machine in terms of oil yield, extraction efficiency and extraction loss with respect to heating temperature and heating time was done accordingly at the fabrication workshop of the Department of Agricultural and Biosystems Engineering, University of Ilorin, Ilorin, Nigeria. The experiment for the performance evaluation was conducted with a $3 \times 2$ factorial experiment in a Randomized Complete Block Design (RCBD) with three replicates. The two factors considered were heating temperature $(\mathrm{T})$ with three levels $\left(50^{\circ} \mathrm{C}, 60^{\circ} \mathrm{C}\right.$ and $\left.70^{\circ} \mathrm{C}\right)$ and heating time $(\mathrm{t})$ with two levels (5 min and 10 min). Heating temperatures were used as the blocking factor while heating times were randomized under each block. A uniform quantity $(100 \mathrm{~g}$ per experimental run) of prepared groundnut seeds was used for the oil extraction operation. The equations used for the estimation of the three performance indices were as stated in [7]. Other equipment used were: digital weighing balance (OHAUS CL Series, Model CL 201, China, accuracy: 0.1), stop watch (Nokia X2-01), and oil bottles and containers.

\section{RESULTS AND DISCUSSION OF PERFORMANCE EVALUATION}

The results and discussions presented here will focus on the effects of heating temperature and heating time on Oil yield, Extraction Efficiency and Extraction Loss
The effects of heating temperature and heating time on oil yield, extraction efficiency and extraction loss are shown in Figures 12-14

Figure 12 shows an irregular pattern in the values of oil yield with increase in heating temperature up to $60^{\circ} \mathrm{C}$. The highest value of $30 \%$ oil yield was obtained at $60^{\circ} \mathrm{C}$ and $10 \mathrm{~min}$ heating temperature and heating time respectively. The drop in value of oil yield obtained after $60^{\circ} \mathrm{C}$ heating temperature could be due to evaporation of oil at higher processing temperature as a result of increase in kinetic energy of oil molecules or prevention of outward movement of oil due to possible formation of burnt cakes on the surface of groundnut particles in the extraction chamber. Akinoso et al., [1] obtained $47.0 \%$ oil yield from palm kernel using mechanical extraction process. Odewole et al., [7] obtained highest value of oil yield of $20.92 \%$ during the solvent extraction of oil from fluted pumpkin seed with $60 \%$ n-hexane. Garcia-Fayos et al., [22] got oil yield values of between $15-17.18 \%$ and $31-34.37 \%$ from Moringa oleifera seeds with manual and soxhlet extraction methods respectively.

Figure 13 shows that the highest value (48\%)and lowest value $(15 \%)$ of extraction efficiencies were obtained at $50^{\circ} \mathrm{C}$ and $5 \mathrm{~min}$, and $70^{\circ} \mathrm{C}$ and $5 \mathrm{~min}$ heating temperature and heating time, respectively. The possible reason for the highest value of extraction efficiency obtained could be due to the mild effect of heating temperature and short processing time which 
would not probably lead to burning of groundnut particles and evaporation of oil being liberated. Ajibola,[23] reported 64\% extraction efficiency from palm kernel oil using hydraulic press and Odewole et al.,[7] got about 97\% extraction efficiency from fluted pumpkin seed using 100\% n-hexane.

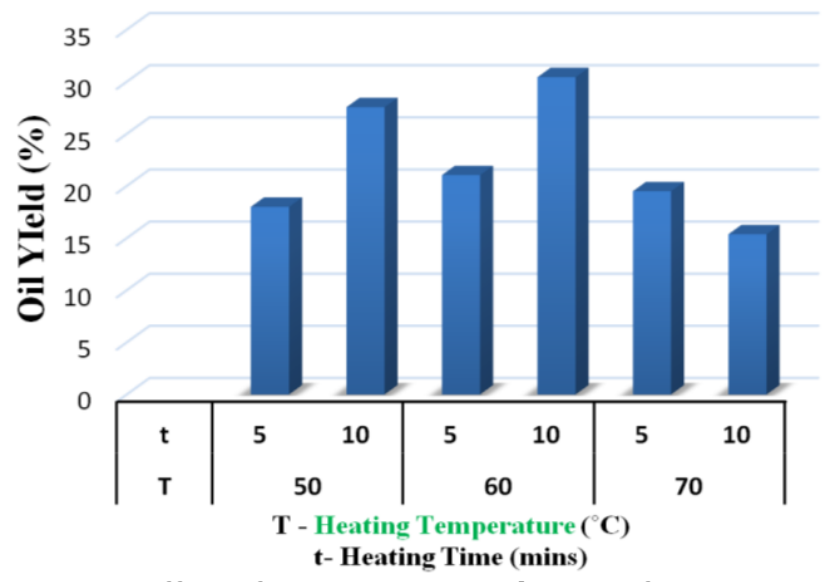

Fig. 12: Effect of Temperature and Time of Heating on Oil Yield

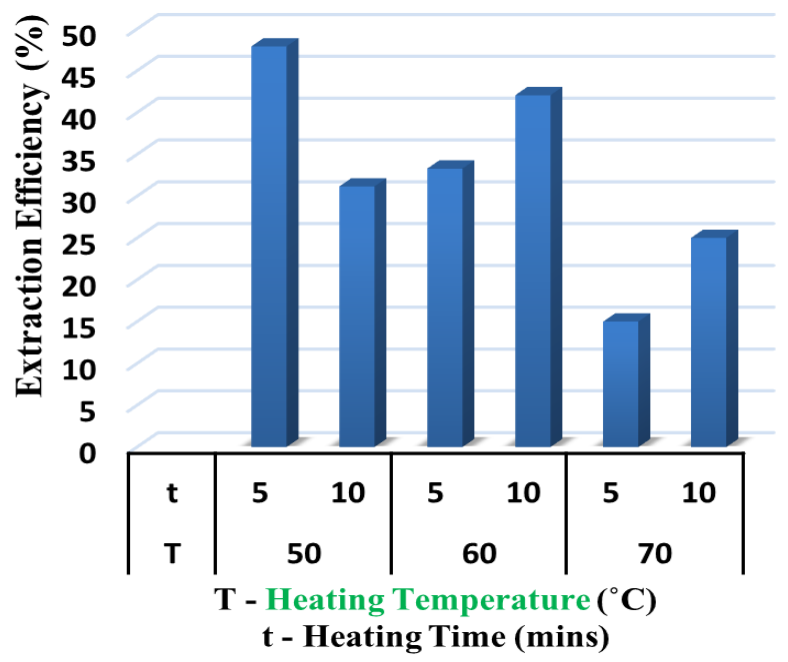

Fig. 13: Effect of Temperature and Time of Heating on Extraction Efficiency

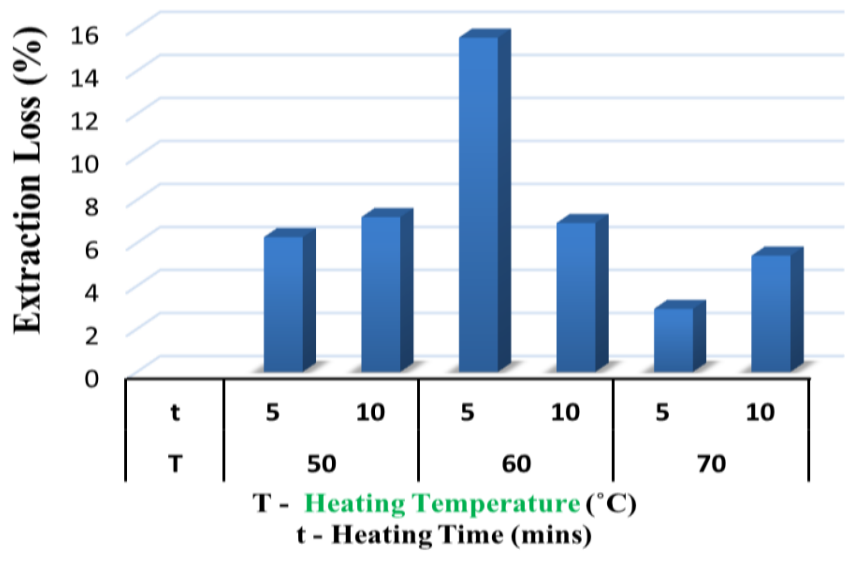

Fig. 14: Effect of Temperature and Time of Heating on Extraction Loss

From Figure 14 the highest extraction loss of about $15 \%$ was obtained at $60^{\circ} \mathrm{C}$ heating temperature and 5 min heating time. Odewole et al., [7] got extraction loss in the range of $2.495 \%-16.122 \%$ from oil extraction from fluted pumpkin seed using n-hexane as the solvent. The highest value of $15 \%$ of extraction loss obtained in this work compared to lower values of those at other levels could be due to human factors associated with improper handling of the machine/extraction process at that particular combination of heating temperature and time.

\section{CONCLUSIONS}

A U-channel screw jack for vegetable oil extraction was developed through design and fabrication processes. The performance evaluation of the machine showed that increase in heating temperature (from 50 to $70^{\circ} \mathrm{C}$ ) and heating time (from 5 to $10 \mathrm{~min}$ ) did not cause the oil yield, extraction efficiency and extraction loss to increase beyond 30\%, 48\% and 15\% respectively. Decrease in oil yield, extraction efficiency and extraction loss generally occurred at the heating temperature of $70^{\circ} \mathrm{C}$ irrespective of the heating time. For future works, other machine and feedstock factors should be incorporated into the performance evaluation process. Also, automation of the machine is recommended.

\section{REFERENCES}

[1.] Akinoso R., Igbeka J. and Olayanju T."Process Optimization of Oil Expression from Sesame Seed (SesamumindicumLinn.)." Agricultural Engineering International: the CIGR Ejournal. Manuscript FP 06 011. Vol. VIII. December, 2006.

[2.] Usman, L. A., Oluwaniyi, O. O., Ibiyemi, S. A., Muhammad, N. O. and Ameen, M. O. "The Potential of Oleander (Thevetia peruviana) in Africa Industrial Industry Development: A Case Study of Nigeria." Journal of Applied Biosciences, 24:, pp. 1477-1487. 2009.

[3.] USDA, Oil seeds: World Markets and Trade Circular Series FOP 01 - 04 January 2004.

[4.] Akinoso R. "Effect of moisture content, roasting duration and temperature on yield and quality of palm kernel (Elaeis guineensis) and sesame (Sesa mumindicum) oils." Ph.D. thesis, University of Ibadan. Nigeria, pp. 1-8. 2006.

[5.] Wilfred S., Adubofuor J. and Oldham J. H."Optimum conditions for expression of oil from Allanblackia floribunda seeds and assessing the quality and stability of pressed and solvent extracted oil." African Journal of Food Science, 4(9):, pp.563 - 570, 2010.

[6.] Bachmann J. Small-Scale Oilseed Processing. ATTRA Value-Added and Processing Guide. 2001.

[7.] Odewole, M. M., Sunmonu, M. O., Obajemihi, O. I and Owolabi, T. E. "Extraction of Oil from Fluted 
Pumpkin Seed (Telfairia occidentalis) by Solvent Extraction Method." Annals. Food Science and Technology (AFST) Journal. Vol.16 No. 2: pp. 372378. Available online at: www.afst.valahia.ro. 2015,

[8.] Nwabanne, J. T. "Kinetics and Thermodynamics Study of Oil Extraction from Fluted Pumpkin Seed." International Journal of Multidisciplinary Sciences and Engineering, Volume 3. No.6, pp. 1115. 2012,

[9.] Isobe, S., Zuber, F., Uemura, K and Noghuchi, A. A New Twin Screw Press Design for Oil Extraction of Dehulled Sunflower Seed. Journal American Oil Chemistry Society. Vol.69: 884-889. 1992.

[10.] Akerele, O. V and Ejiko, S. O. Design and Construction of Groundnut Oil Expeller. International Journal of Engineering and Computer Science. Vol. 4(6): 12529-12538. 2015.

[11.] Adetola, O. A., Olajide, J. 0 and Olalusi, A. P. Development of A Screw Press for Palm Oil Extraction. International Journal of Scientific and Engineering research. Vol. 5(7): 1416-1422. 2014.

[12.] Adeeko, K. A and Ajibola, 0. O . Processing Factors Affecting Yield and Quality of Mechanically Expressed Groundnut Oil. A Review: Journal of Agricultural Engineering Research. Vol.45: 31-43. 1990.

[13.] Tunde-Akintunde, T. Y., Akintunde, B. O., and Igbeka, J. C., Effects of Processing Factors on Yield and Quality of Mechanically Expressed Soybean Oil. Journal of Engineering Technology. 1(9): 3945. 2001.

[14.] Olaniyan, A. M. Effect of Extraction Conditions on the Yield and Quality of Oil from Castor Bean. Journal of Cereals and Oilseeds, 1(2); 24-33. 2010.

[15.] Sridhara R. V. V., Bala K.M. V., Suresh K. J. and Vijaya K. R. K. "Effect of Thickness Ratio on Nonlinear Static behavior of Skew Bidirectional
FRP Laminates with Circular Cutout. "International Journal of Applied Engineering Research, Vol. 1, No. 4: pp. 923-932. 2011,

[16.] Khurmi, R. S. and Gupta, J. K. Textbook of Machine Design, S. Chand Eurasia publishing house (pvt.) Ltd, Ram Nagar, New Delhi. 2005.

[17.] Woodson, W. and Conover, D.W. Human Engineering Guide for Equipment Design, 2nd. Edition Univ. of Calif. Press, 1964. In NASA Human Performance Capabilities Vol. 1 https://msis.jsc.nasa.gov/sections/section04.htm, 2008.

[18.] Chen Yong-dang. "Finite Element Method Based on Solid Works Simulation" [J].CAD/CAM YU ZHIZAOYE XINXIHUA, Vol. 9, pp. 48-51. 2011,

[19.] Kurowski, P. M. Thermal analysis with Solidworks Simulation 2015 and Flow Simulation 2015. Published by Schroff Development Corporation, 2015.

[20.] Rao, D. G. Fundamentals of Food Engineering published by Asoke K. Ghosh PHI Learning Limited, M-97, Connaught Circus New Delhi$110001,2012$.

[21.] Lu Zhou-yan, Zhao Zhi-jun, and Li Liu. "Finite Element Analysis for Planetary Carrier of Roller Press Planetary Reducer." [J] Coal Mine Machinery, 2011, pp. 2009-2012.

[22.] Garcia-Fayos, B., Arna, J. M., Verdu, G and Sauri, A. "Study of Moringa oleifera Oil Extraction and Its Influence in Primary Coagulant Activity in Drinking Water Treatment." International Conference on Food Innovation, Universidad Politécnicade Valencia, Spain. 25 $5^{\text {th }}-29^{\text {th }}$ October, 2010.

[23.] Ajibola, 0. O. "A study of some factors affecting hydraulic press of palm kernel." Journal of Food Science and Technology (India) 26 (4): pp. 213217. 1989. 